\title{
How organizational commitment of critical care nurses influence their overall job satisfaction
}

\author{
Ngozi I Moneke', Ogwo Jay Umeh² \\ 1. New York-Presbyterian Hospital-Weill Cornell Medical Center, New York, NY, USA. 2. Department of Public Affairs and \\ Administration, California State University, East Bay, Hayward, CA, USA.
}

Correspondence: Ngozi I Moneke, DHA, RN, MSN, ANP, CCRN-CMC. Address: 253 S. Long Beach Avenue, Freeport, New York, NY 11520, USA. Email: ngomoneke@aol.com

Received: J une 12, 2013

DOI : $10.5430 /$ jnep.v4n1p148
Accepted: July 8, $2013 \quad$ Online Published: September 4, 2013

URL: http://dx.doi.org/10.5430/jnep.v4n1p148

\section{Abstract}

Background: Job satisfaction is an important component of nurses' lives that can have an effect on patient satisfaction and safety, productivity and performance, quality of care, retention, turnover, and commitment to the organization and the profession. Job dissatisfaction affects nurses' commitment to the organization.

Methods: This non-experimental, quantitative study was conducted of critical care nurses who practice in a non-profit healthcare organization in New York City. The study consisted of a purposive sample of 204 critical care nurses who were employed in various critical-care units such as medical intensive care units (MICU), cardiothoracic intensive care unit CTICU) Cardiac care unit (CCU), neuroscience intensive care unit, burn intensive care unit, and surgical intensive care unit( SICU). Two pre- existing, validated instruments (Organizational Commitment Questionnaire and Job in General scale) was used to gather data for the current study. Statistical analysis of data was performed.

Findings: There is a significant correlation between Organizational commitment and Job Satisfaction $(r=.66, p=.00)$. The regression model examining the association between gender, age, years as an RN, years with current employer, highest educational degree and job satisfaction (the dependent variable) was not statistically significant $(F(5,87)=.605, p$ $=.69$ ). The ANOVAs for the impact of ethnicity, specialty certification, specialty area, title, shift, and employment status were not statistically significant $(p>.05)$.

Conclusion: The relationship between critical care nurses' organizational commitment and job satisfaction reaffirms the importance of nurse leaders routinely monitoring nurses' satisfaction and implementing strategies that address the dimensions of job satisfaction.

\section{Key words}

Organizational commitment, Job satisfaction, Nurses’ job satisfaction, Nurses' retention

\section{I ntroduction}

The health care industry is unique and its success is measured by financial returns as well as its ability to effectively act upon the needs of all customers, thereby improving the delivery of care and achieve organizational results ${ }^{[1]}$. Healthcare is driven by the needs of patients in which critical-care nurses provide their optimal contribution. A critical-care nurse is a diploma or baccalaureate graduate nurse who practices in a specialized environment which has been formed for the patient 
population with a variety of life threatening illnesses or conditions. It is a person who is licensed under the provision of an appointed state board to practice professional nursing (Registered Nurse) as defined by the Nurse Practice Act of each state ${ }^{[2]}$. Critical-care nursing as defined by the American Association of Critical-care Nurses ${ }^{[3]}$, "is that specialty within nursing that deals specifically with human responses to life-threatening problems” (p.1). A critical-care unit includes a specific workplace within a hospital involving the care of very sick patients using specially trained nurses to conduct frequent observations, immediate interventions and the use of highly technological monitoring equipment or device.

According to Carr ${ }^{[4]}$, surgical or medical intensive care units, "shock-trauma” and “step-down” units, burn unit, neurosurgical ICUs, and emergency room (ER) setting are considered critical-care units. For the current study, cardiac care unit, surgical ICU, medical ICU, cardiothoracic ICU, the neuro-ICU, and the burn-ICU, are the critical-care units selected for the current study. American Association of Critical-Care Nurses (AACN) ${ }^{[3]}$ stated that critically ill patients as those patients who are at high risk for actual or potential life-threatening health problems. A critically ill patient is highly vulnerable, unstable and complex, requiring intense and vigilant nursing care ${ }^{[3]}$. Hain ${ }^{[5]}$ explained that the presence of the nurse at the bedside is valuable for the care of the critically ill.

Carr ${ }^{[4]}$ postulates that the population of critical care patients will increase due to higher life expectancy. He reports that, annually, more than five million patients are currently admitted to critical care settings ${ }^{[4]}$. This increase in the number of patients will further result to increase shortage and the demand for critical care nurses ${ }^{[4]}$.

Organizational commitment is the ability of an employee to act in such a way that meets the organization's goals and interests. Employing committed employees is essential to organizations. Mowday, Steers, and Porter ${ }^{[6]}$ noted the importance of commitment in understanding the work behavior of employees in organizations. In the nursing profession, commitment is critical ${ }^{[7]}$. Empirical evidence indicates that there is a direct correlation between staff satisfaction and patient satisfaction in healthcare organizations ${ }^{[8]}$. Organizational culture of trust and justice can be measured by the level of nurses' satisfaction, commitment, and the quality of care that are rendered to the customers ${ }^{[7]}$. Studies about organizational commitment are prevalent as the pursuit to improve organizational effectiveness and commitment, especially in nursing profession. Previous studies indicated that unsatisfied health care employees negatively affect the quality of care with adverse effects on patient satisfaction and loyalty to the organization ${ }^{[9,10]}$. Research showed that organizations that promote job satisfaction and career satisfaction reap the benefits of increased retention and reduced attrition ${ }^{[11]}$.

Nogueras ${ }^{[12]}$ examined how intent to leave nursing predicted job commitment, education, and experience. A sample of 908 nurses participated in the study. Correlation between Registered nurse continuance commitment and intent to leave nursing revealed a relationship that was significant $(r=-.14, p=.00)$. The results implied the more continuance commitment Registered Nurses experienced, the less likely they were to leave nursing. Krichbaum et al. ${ }^{[13]}$ blamed job dissatisfaction and lack of organizational commitment on the part of nurses on something they call "Complexity Compression" (CC). Krichbaum et al. ${ }^{[13]}$ used an inductive method to define CC as "the increasing complexity of systems and clients and the increasing demands from both” (p. 87). Using focus groups and open discussions, Krichbaum et al. ${ }^{[13]}$ concluded that increasingly stressful and complex demands on nurses have created a new phenomenon (i.e., Complexity Compression) that is causing widespread job dissatisfaction among modern day nurses.

Commitment to an organization occurs to the extent that employees perceive some beneficial or equitable exchange relationship ${ }^{[14]}$. Employees who feel that they are cared for by their organization and managers also have not only higher levels of commitment, but they are also more conscious about their responsibilities, have greater involvement in the organization, and are more innovative. Research indicated that employee commitment is antecedent to and inversely correlated with turnover intentions and turnover ${ }^{[14]}$. Wu and Norman ${ }^{[15]}$ studied a sample of full-time final-year degreelevel Chinese nursing students. Wu and Norman found a positive correlation between job satisfaction and organizational commitment $(r=.464, p<.01)$, indicating that student nurses who were more satisfied with nursing as a job were also more likely to be committed to the nursing profession. Job satisfaction is vital to nurses' lives that can affect patient safety, 
productivity and performance, quality of care, retention and turnover, commitment to the organization, and to their profession ${ }^{[16]}$. Study showed that job satisfaction of nurses not only affects them individually, but also affects to the organization $^{[17]}$.

Al-Hussani ${ }^{[18]}$ revealed a strong association $r(55)=.90, p<.05$ between job satisfaction an organizational commitment. Supporting these findings is a descriptive and explorative study done by Altuntas and Baykal ${ }^{[19]}$, to investigate both the levels of nurses' organizational trust and citizenship, and also the relationship between the two factors. Altuntas and Baykal found that the nurses' level of organizational trust was directly associated with positive citizenship organizational behaviours, such as conscientiousness, courtesy, altruism and civic virtue. Spector ${ }^{[20]}$ stated that job satisfaction is how people feel about their jobs and different aspects of their jobs. Spector ${ }^{[20]}$ suggested that job satisfaction is important for three reasons: (1) The humanitarian perspective which required that people respected and treated fairly which is a reflection of good treatment to the employees, (2) The utilitarian perspective is that job satisfaction can lead to behavior by employees that affect organizational functioning, and (3) Job satisfaction can be a reflection of organizational effectiveness.

In today's competitive health care environment, recruiting and retaining top talent is very essential in meeting the demand for quality patient care and management. Study showed that healthcare organizations that implement strategic initiatives that enhance staff satisfaction have higher Healthcare Consumers Assessment of Hospital Performance (HCAHP) scores, higher reimbursement, and revenue ${ }^{[21]}$. Organizational performance such as productivity, retention, customer service and loyalty, employee retention, and turnover correlate to employee engagement to the organization ${ }^{[22,23]}$. Nurses with higher job satisfaction care about the quality of their work, are more motivated and committed to the organization, are more productive, and have higher retention rates ${ }^{[24,25]}$. Nurses who feel that their contributions are noticed experience satisfaction, and nurses who experience satisfaction stay where they are, contributing to organization retention ${ }^{[26]}$.

Employees who are satisfied with their work are more engaged more productive, creative, and commitment to their organization ${ }^{[23]}$. The demand for critical care nurses is high ${ }^{[27]}$. The unique work settings in critical care nursing, impacts job satisfaction among nurses and patient care outcomes ${ }^{[28]}$. The work environments in critical care nursing ${ }^{[29]}$ and burnout and stress have a relationship to job satisfaction of nurses ${ }^{[30]}$. Job dissatisfaction of nurses affects commitment to the organization ${ }^{[31,32]}$. It has been noted that critical-care setting is a stressful environment and the existence of nurse shortage further increases stress among critical-care nurses.

In addition, the intensive care environment also can bring moral distress and ethical dilemmas to nurses during the care of the dying patient ${ }^{[33]}$. Such distress and ethical dilemmas affect nurses’ personal satisfaction with patient care ${ }^{[34]}$. An understanding of the factors that promote nurses' job satisfaction is very important. Coffey and Tombari ${ }^{[35]}$ stated that the successful outcome of any enterprise depends on the diversity of its human capital, including each individual's creativity, integrity, commitment to quality, and customer care.

\section{Research question}

To what extent is there a relationship between critical-care nurses' commitment to their organization and their overall job satisfaction?

\section{Hypothesis}

H1: A significant relationship will be found to exist between organizational commitment and job satisfaction and critical-care nurses'.

The conceptual frameworks of the current study are the Abraham Maslow's ${ }^{[36]}$ hierarchy of needs, Herzberg's ${ }^{[37]}$ dual factor theory. Maslow and Herzberg have identified motivation as a key factor in job satisfaction with emphasis on social, safety and psychological rewards. According to Maslow, motivating someone entails focusing on satisfying the needs of 
the person, based on the level on the hierarchy the person is on. According to Herzberg, when hygiene factors are met, there is a lack of dissatisfaction, not an existence of satisfaction. Likewise, the absence of motivators does not necessarily cause dissatisfaction ${ }^{[37]}$.

\section{Subjects and methods and ethical considerations}

The purpose of this quantitative study with a correlational design was to determine the influence of critical care nurses' commitment to their organization have on their overall job satisfaction. The other purpose of the study was to help healthcare leaders in gaining a better understanding and increased awareness of nurses' organizational commitment and job satisfaction issues in the critical-care environment. It is hoped that this understanding will be helpful in mitigating the nursing shortage, lower nurse turnover rates, promote patient safety, improve patient and nurse satisfaction, and cost reduction. Approval was obtained from the organization’s Institutional Review Board (IRB) to conduct the study.

The participants' confidentiality was maintained. All participants' responses were kept confidential and were only available to the researcher and the statistician. Demographic information requested as part of the study was not marked or coded on an individual basis. The survey was Internet-based and, thus, accessible to participants via a URL. An Internetbased data collection organization hosted the survey and initially stored survey responses.

The target population for the study consisted of critical care nurses in a diverse critical care unit at a non-profit healthcare organization, in New York City. The demographic information was examined in an effort to understand the interrelationships between critical care nurses' organizational commitment and their overall job satisfaction. Sample inclusion criteria were intensive care nurses in MICU, CCU, CTICU, SICU, NEURO, AND BURN unit, either full time, part- time, or per diem basis and have been employed by the organization for a minimum of 6 months. Exclusion criteria were nurses who did not meet the above criteria and those who were nurse managers, nursing supervisors, clinical nurse specialist, nurse practitioners, nurse aides, and allied healthcare staff. The nurses participated in the study by accessing a welcome page Web site that linked the participants to an informed consent page and then to the survey and a demographic questionnaire. The communiqué series included (a) pre notification letter (b) Week 2 reminder, (c) Week 3 reminder, (d) Week 4 reminder, and (e) end-of-survey thank you letter.

Out of the 204 that were invited via email, 137 Critical care nurses voluntarily participated in the study, resulting in a response rate of $67 \%$. Of the 137 who responded, $81 \%$ (112) completed the survey in its entirety. The majority of the sample was female (77\%). The largest age distribution of participants was between the ages of 29-38. The frequencies and percentages for the other variables can be found in Table 1.

\section{Study instruments}

Two validated, pre-existing instruments were used to gather data for the study:

\section{Organizational Commitment Scale (OCQ)}

The OCQ uses a 7-point Likert-type ranging from 1 (strongly disagree) to 7 (strongly agree), has 15 items, six of which are reverse scored and negatively phrased. Examples of items include "I feel very little loyal to this organization" and "I really care about the fate of this organization.” Coefficient alphas ranged from 0.82 to 0.93 with a median of 0.90 and test-retest reliability coefficients were $0.53,0.63$ and 0.75 for 2-, 3- and 4-month periods, respectively ${ }^{\text {[38] }}$. The Cronbach's alpha was 0.86 in this study. Mowday et al. ${ }^{[38]}$ defined organizational commitment as "an employee's desire to remain attached to an organization and work to help accomplish its goal” (p. 225). The organizational commitment scale measures an employee's belief in and acceptance of the organization's goals, their willingness to expend effort and their desire to maintain membership in the organization. For the purpose of the current study, the OCQ was the preferred instrument choice because it is a 1-dimenstional scale ${ }^{[39]}$. 
Table 1. Descriptive of Demographic Variables

\begin{tabular}{|c|c|c|c|}
\hline \multicolumn{4}{|c|}{ Study Findings: Sample Demographic Characteristics } \\
\hline \multicolumn{2}{|l|}{ Variable } & \multirow{2}{*}{$\begin{array}{l}\text { Frequency } \\
53\end{array}$} & \multirow{2}{*}{$\begin{array}{l}\text { Percentage } \\
40.8\end{array}$} \\
\hline Age & $29-38$ & & \\
\hline$n=130$ & $39-48$ & 33 & 25.4 \\
\hline & $18-28$ & 25 & 19.2 \\
\hline Gender & Female & 85 & 77.0 \\
\hline $\mathrm{n}=110$ & Male & 25 & 23.0 \\
\hline \multirow{3}{*}{$\begin{array}{l}\text { Ethnicity } \\
\mathrm{n}=114\end{array}$} & White & 63 & 55.3 \\
\hline & African-American & 26 & 22.8 \\
\hline & Hispanic/Latino & 14 & 12.3 \\
\hline Level of Education & Bachelor in nursing & 73 & 56.6 \\
\hline $\mathrm{N}=129$ & Masters in nursing & 23 & 17.8 \\
\hline Years of & $6 \mathrm{mths}-4 \mathrm{yrs}$ & 44 & 34.9 \\
\hline Employment & 5-9yrs & 40 & 31.7 \\
\hline $\mathrm{n}=126$ & $10-14 y r s$ & 26 & 20.6 \\
\hline $\begin{array}{l}\text { Employment status } \\
\mathrm{N}=126\end{array}$ & Full time & 116 & 90.6 \\
\hline Shift & Day & 63 & 48.8 \\
\hline$n=125$ & Night & 54 & 41.9 \\
\hline \multirow{3}{*}{$\begin{array}{l}\text { Title } \\
n=127\end{array}$} & Staff nurse & 84 & 67.2 \\
\hline & Senior staff nurse & 28 & 22.4 \\
\hline & Nurse clinician & 13 & 10.4 \\
\hline Certification & CCRN & 55 & 93.2 \\
\hline $\mathrm{n}=59$ & CMC & 4 & 6.8 \\
\hline
\end{tabular}

\section{J ob I n General ( J I G)}

The questionnaire consists of 18 items developed by Smith ${ }^{[40]}$ to measure overall job satisfaction to dissatisfaction. The instrument consists of an 18 one-to-three word adjectives describing the employee's feelings about their job in general. Responses include yes, no, or? if uncertain about their feelings. A positive response scores three, a negative response scores zero and a? or blank scores 1 . All negatively worded items are reverse scored such that yes $=0, n o=3$, and? $=1$. A higher overall score or mean score indicates greater job satisfaction and vice versa. Cronbach's alpha was .91 to $.95{ }^{[40]}$. Convergent validity was .66 to $.88^{[40]}$. The Cronbach's alpha was 0.87 in this study. For the purpose of the current study, the JIG was the preferred instrument choice. It is a measure of global satisfaction, meaning that participants were asked to think about how satisfied they were with their job in a broad, overall, sense.

\section{Data analysis}

Statistical methods employed for the study were the Pearson product-moment correlational technique, multiple regression techniques, and the analysis of variance (ANOVA). The internal consistency reliability coefficients (Cronbach's alpha) for the scales used in this study are all well above the level of 0.7 , acceptable for the analysis purpose.

\section{Findings}

Based on the data collected, we found that organizational commitment is positively and significantly correlated with job satisfaction. Demographics for the study were described in Table 1. The study predicted that there will be a relationship between organizational commitment and job satisfaction of critical-care nurses. The use of correlational analysis provided the basis for determining that there is a statistically significant, strong, positive correlation between JIG and OCQ $(r=.66$, $p=.00$ ). The nature of the relationship between the JIG and OCQ is reflected in Table 2 
Table 2. Correlations between Organizational Commitment and Job Satisfaction of Critical Care Nurse

\begin{tabular}{lll}
\hline & & JIG total \\
\hline OCQ total & $r$ & .66 \\
& $p$ & .00 \\
$N$ & 112 \\
\hline
\end{tabular}

Note. OCQ = Organizational Commitment, JIG = Job Satisfaction.

The regression model examining the association between gender, age, years as an RN, years with current employer, highest educational degree and Job satisfaction was not statistically significant $(F(5,87)=.605, p=.69)$ and accounted for only $3.6 \%$ of the variance in job satisfaction $\left(R^{2}=.36\right)$. None of the regression coefficients were statistically significant (see Table 3).

Table 3. Regression Coefficients for the Relationship between Gender, Age, Years as Registered Nurse, Years With Current Employer, Highest Educational Degree and Job Satisfaction

\begin{tabular}{llllllll}
\hline Model & $\boldsymbol{B}$ & Std. Error & $\boldsymbol{\beta}$ & $\boldsymbol{t}$ & $\boldsymbol{p}$ & Tolerance & VIF \\
\hline Gender & .096 & .142 & .075 & .672 & .503 & .943 & 1.061 \\
Age & -.079 & .088 & -.161 & -.893 & .374 & .361 & 2.774 \\
Years as a Registered Nurse & .008 & .099 & .017 & .077 & .938 & .256 & 3.907 \\
Years with Current Employer: & .094 & .088 & .216 & 1.065 & .290 & .285 & 3.503 \\
Highest Educational Degree & .009 & .042 & .023 & .207 & .837 & .947 & 1.056 \\
\hline
\end{tabular}

To determine the relationship among job satisfaction and the categorical demographic variables, analysis of variance (ANOVA) was used. The ANOVAs for the impact of ethnicity, specialty certification, specialty area, title, shift, and employment status were not statistically significant $(p>.05)$. The first ANOVA examined the main effect of employment status for job satisfaction. Given the small sample size for the part-time and per diem groups were combined. The ANOVA revealed that there were no significant differences in average job satisfaction by employment status $(F(1,109)=.303, p=$ .58). The plotted means can be found in Figure 1.

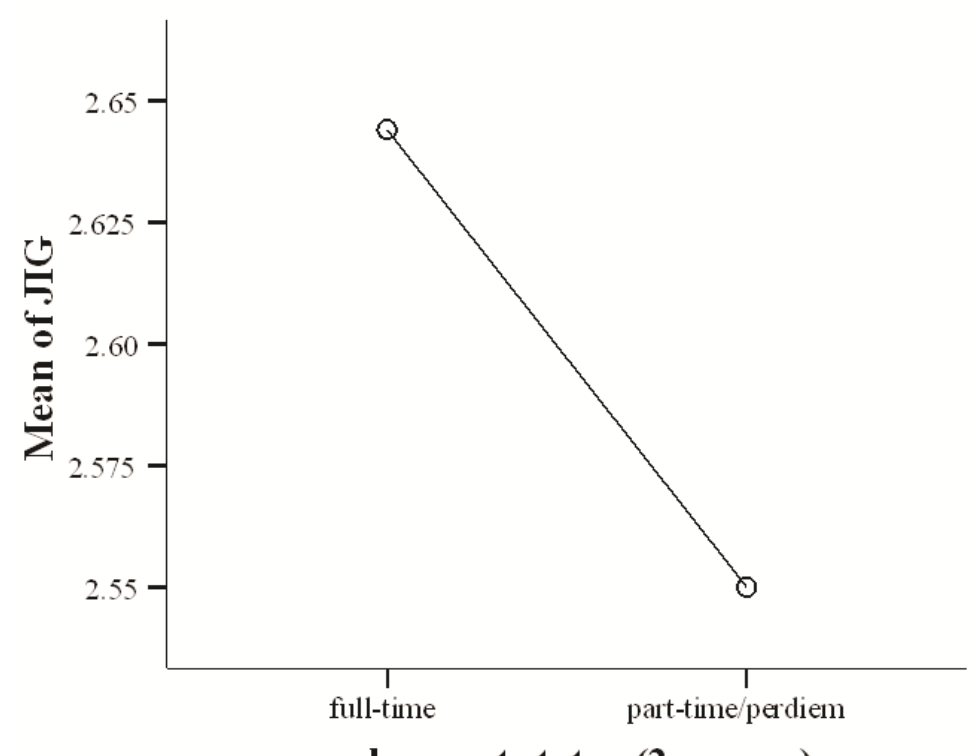

Figure 1. For Job Satisfaction by Employment Status 
The next ANOVA examined the main effect of shift for job satisfaction. Given the small sample size, evening only and rotating groups were combined. The ANOVA revealed there were no significant differences in average job satisfaction by shift $(F(2,110)=1.385, p=.255)$. The plotted means can be found in Figure 2.

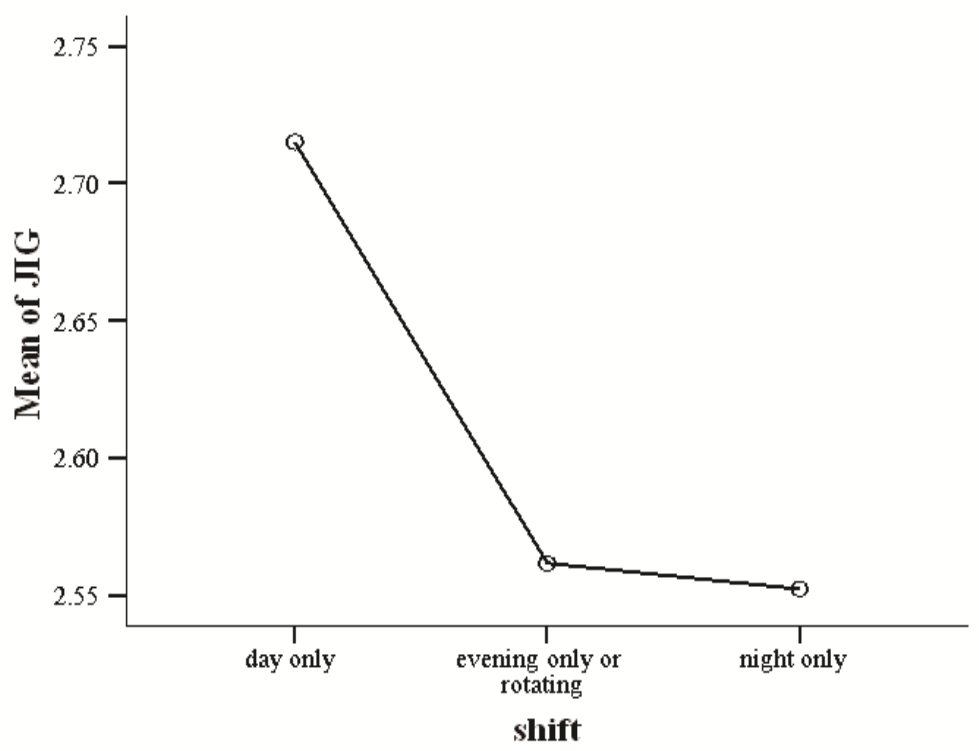

Figure 2. Means Plot for Job Satisfaction and Shift

The next ANOVA examined the main effect of title for job satisfaction. The ANOVA revealed that there were no significant differences in average job satisfaction by title $(F(2,107)=1.220, p=.299)$. The the plotted means can be found in Figure 3.

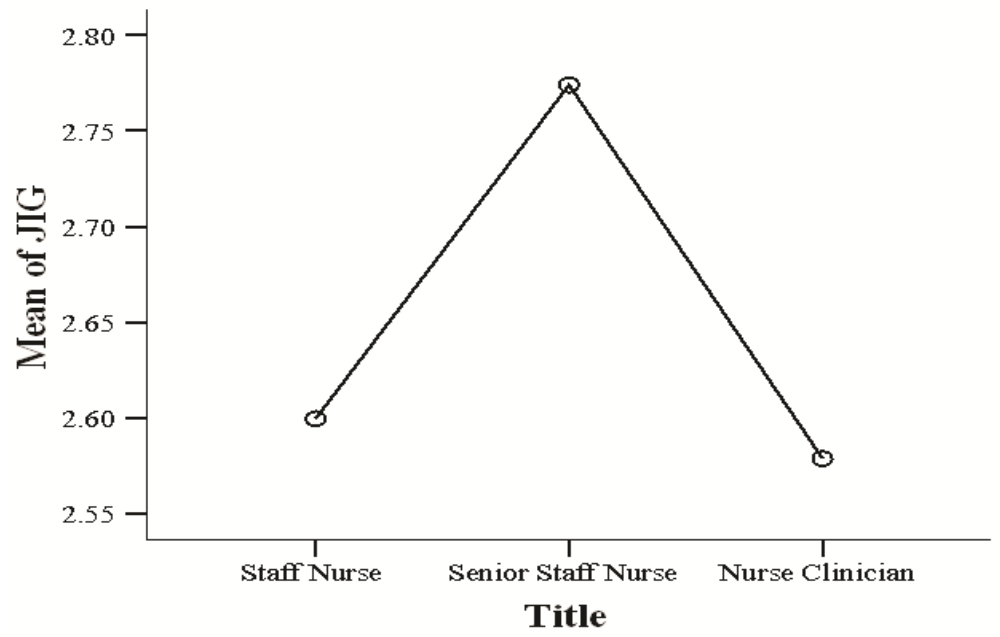

Figure 3. Means Plot for Job Satisfaction and Title

The next ANOVA examined the main effect of specialty area for job satisfaction. The ANOVA revealed that there were no significant differences in average job satisfaction by specialty area $(F(5,111)=1.684, p=.145)$. The plotted means in Figure 4 show that the mean for those who work in the MICU is higher than all other groups, indicating that those nurses who work in MICU setting are more satisfied with their job than other groups of critical care nurses. 


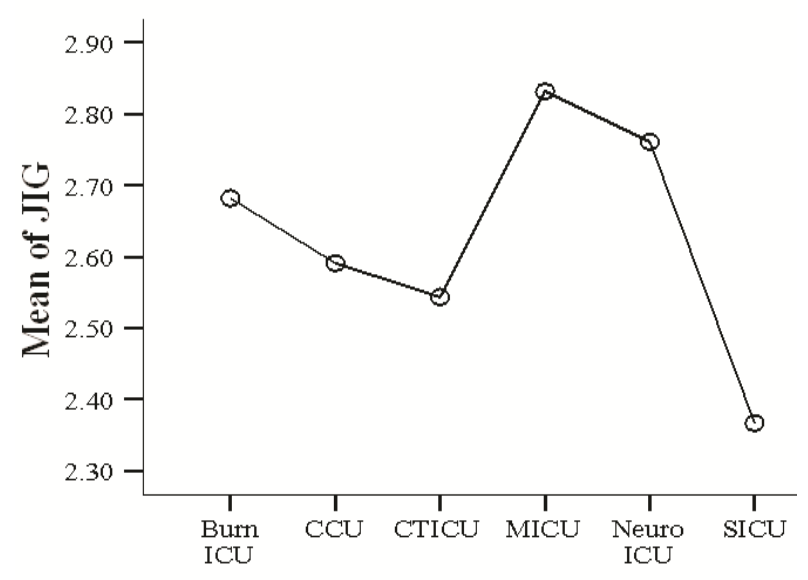

Specialty area

Figure 4. Means Plot for Job Satisfaction and Specialty Area

The next ANOVA examined the main effect of specialty certification for job satisfaction. The ANOVA revealed there were no significant differences in average job satisfaction by specialty certification $(F(1,52)=2.626, p=.111)$. The plotted means can be found in Figure 5.

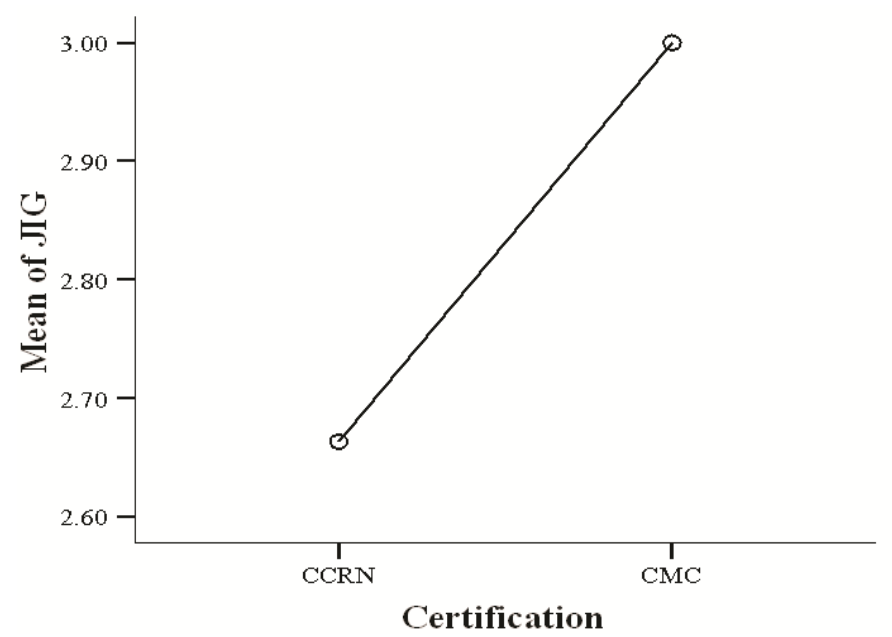

Figure 5. Means Plot for Job Satisfaction and Specialty Certification

The final ANOVA examined the main effect of ethnicity for job satisfaction. Given the small sample size, those who identified as Pacific Islander, two or more races, and other were combined into 1 group. The ANOVA revealed there were no significant differences in average job satisfaction by ethnicity $(F(3,96)=.739, p=.531)$. The plotted means in Figure 6 shows the mean for Hispanic nurses is higher than those of the other ethnic groups, but not significantly higher.

\section{Discussion}

The current study found a significant relationship between organizational commitment and job satisfaction. Nurses' job satisfaction has received increasing attention and enhancing nurse job satisfaction has been emphasized as a major strategy to recruit and retain qualified nurses. Organizational commitment is based on behaviors or attitudes that involve the relationship an employee has with an organization. Commitment includes three factors: a strong belief in, and acceptance of, the organization's goals and values; a readiness to put the effort necessary on behalf of the organization; and the 
willingness to remain part of the organization ${ }^{[41]}$. Research findings revealed that organizational commitment is correlated with job satisfaction ${ }^{[14,18,42]}$ and the current research study also found that organizational commitment was a predictor of

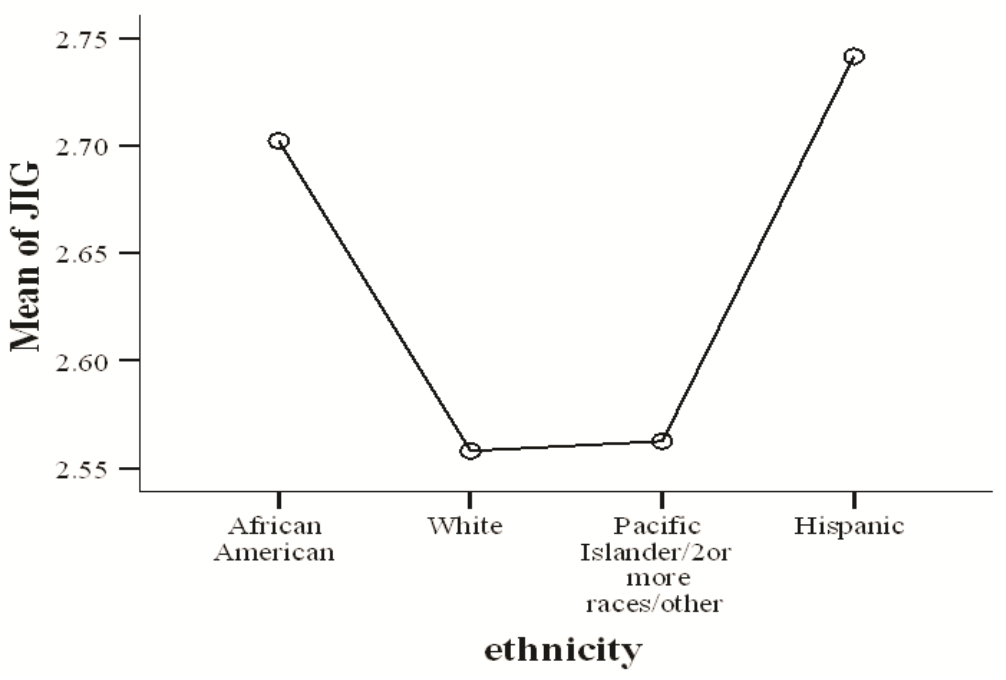

Figure 6. Means Plot for Job Satisfaction and Ethnicity

job satisfaction. Wu and Norman ${ }^{[15]}$ also found a positive correlation between organizational commitment and job satisfaction, indicating that critical care nurses who were satisfied with their job were more likely to be committed to their organization. If job satisfaction is low, then it stands to reason that nurses will not be motivated to perform their jobs as well as necessary to achieve organizational goals, and the industry as a whole will continue to suffer. The findings of nurses' strong organizational commitment in the study is inconsistent with Knoop's ${ }^{[43]}$ survey in Canada, which found that nurses had a low level of organizational commitment. Empirical research confirms a strong positive relationship between perceived work-related support and organizational outcomes such as organizational commitment, turnover intentions and turnover behavior ${ }^{[44]}$. Employee turnover can be extremely damaging and costly for organizations ${ }^{[45]}$. To reduce the costs of turnover it is imperative that healthcare organizations develop effective and efficient strategies of employee retention ${ }^{[23]}$.

The result of the current study did not reveal a significant correlation between level of education and critical care nurses' organizational commitment. This finding supports those of Mathieu and Zajac ${ }^{[46]}$ who reported that level of education was negatively correlated with organizational commitment. This finding is inconsistent with previous studies, which found that education is a significant predictor of organizational commitment ${ }^{[47,48]}$. The current study did not find a relationship between critical care nurses' age, gender, educational level, ethnicity, numbers of years as a nurse, and number of years with the current employer and job satisfaction. These findings are consistent with the study by Paige ${ }^{[49]}$. It is also congruent with the results of Kessuwan and Muenjohn ${ }^{[50]}$ who found that educational level was not related to job satisfaction. However, other research findings revealed a positive correlation between nurses' level of education and job satisfaction ${ }^{[18,51]}$. The largest age distribution of participants are between the ages of 29-38 which indicates that, in this healthcare organization, the nurses are young adults, which further suggests that young women are motivated to join nursing profession. Different generational cohorts were represented in this study. Nursing leaders must be aware of the differences in generations in other to have a workforce that works together and enhance organizational goals. Another interesting finding in this study is that, over half of the respondents (56.5\%) have a Bachelor's degree in nursing. A Bachelor's degree in nursing is now being advocated as the minimum qualification to join the nursing workforce in the United States; therefore it further suggests that the participating nurses in the current study fulfilled the minimum requirement to become the registered nurses as per the United States nursing board regulations to practice nursing. 
The current study revealed that certification was not related to job satisfaction for critical care nurses. Niebuhr and Biel ${ }^{[52]}$ drew the same conclusion by not finding any differences among nurses with specialty certification and nurses who were not certified. However, the literature indicated a relationship between specialty certification and job satisfaction. Studies by Piazza, Donahue, Dykes, Griffin, and Fitzpatrick ${ }^{[53]}$ and Fitzpatrick, Campo, Graham, and Lavandero ${ }^{[54]}$ found nurses certified in critical care indicated greater satisfaction with their jobs than nurses who were not certified. With the challenge and complexity of healthcare today, specialty certification has become a mark of excellence. Certification validates nurses' skills, knowledge and abilities, and empowers nurses within their professional sphere of activity and contributes to better patient outcomes. In the current economy, being certified may help a nurse survive staff cutbacks and to be more competitive in the job market. Ulrich et al. ${ }^{[55]}$ reported that in the 2008 follow-up survey of critical care nurses' institutional support for certification was related to nurse satisfaction. Studies revealed that specialty certified nurses have higher rates of patient satisfaction and lower rates of errors ${ }^{[56]}$. Also important is the benefit of personal satisfaction and increased confidence that comes from passing a certification examination ${ }^{[57]}$.

The current study did not find a statistically significant relationship among critical care nurses' years of service, job position, and job satisfaction. This finding is inconsistent with Ma, Samuels, and Alexander ${ }^{[58]}$ who found statistically significant differences between job satisfaction and years of service, job position, hospital retirement plan, and geographic area. Again, we did not find a statistically significant relationship among shifts work and job satisfaction of critical care nurse. Coincidentally, this finding is supported by Ruggiero ${ }^{[59]}$ who did not find significant differences among critical care nurses' self-defined day, night, and rotating-shift nurses Employees in organizations may be motivated to contribute their ideas and talents and may be quite satisfied with their job in an environment that fosters growth of the employees and where their knowledge, skills and abilities are valued and fully used. Employees who feel that they are cared for by their organization will have not only higher levels of commitment, but are also more conscious about their responsibilities, have greater involvement in the organization, and are more innovative.

Study showed that factors that positively affect job satisfaction of critical-care nurses will promote retention, while those factors that negatively affect job satisfaction will lead to more turnover and therefore worsen the nursing shortage ${ }^{[60]}$. Employees in organizations may be motivated to contribute their ideas and talents and may be quite satisfied with their job in an environment that fosters growth of the employees and where their knowledge, skills and abilities are valued and fully used.

\section{Study limitations}

This research may have been limited by the number of participants who voluntarily completed the survey questionnaire. The sample in this study was limited to critical care nurses working in one teaching hospital in the United States of America. Thus, the generalization of the findings needs to be treated with caution. Purposeful sampling limited applicability of results to nurses in other health care settings; and might also limit the overall generalizability of the study. The current study used online survey for data gathering. Because solicitations for voluntary participation were sent out through the hospital e-mail, some critical care nurses may have ignored the e-mail, or postponed answering it, and thus missed the deadline for the survey. In addition, lack of time may have prevented the nurses from accessing the survey and they may not have tried to access the survey from their homes.

\section{Conclusion and implication}

The current study expands organizational commitment and job satisfaction research by substantiating statistically significant relationship between organizational commitment of critical care nurses and their overall job satisfaction. In addition, the current study strengthens the evidence that the more committed nurses are to their organizations, the more effective 
and productive they would be in their organizations. Improved job satisfaction and retention of critical-care nurses may result in improved patient satisfaction, quality care, and increased revenue for the organization.

Nursing research and education may use the result of the current study to further comparative studies within nursing practice. Nurse managers as well as health policy makers may benefit from the findings of the current study. Identification of factors that result in job satisfaction is essential for an organization so that the organization can implement the necessary changes to maintain critical-care nurses' job satisfaction and retention. Nurses working in a critical care environment may benefit from efforts taken by nursing leaders in promoting a workplace with high emphasis on patient safety through nurse job satisfaction ${ }^{[61]}$. Hospital administrators may incorporate the findings into practice to create a positive work environment, enhance employee satisfaction and promote quality care, and improve the organization's human capital investment and effectiveness.

\section{Recommendations}

There will be a need for further studies to test the applicability of the findings of the current study, by extending and expanding the investigation to similar critical care setting and other healthcare environments within the United States. In addition, it would be beneficial to conduct a similar survey using the same questionnaires (OCQ and JIG) in other geographic locations within the United States and outside the United States in order to compare the influence of job satisfaction, including areas such as progressive care units, medical/surgical units, emergency departments, labor and delivery, operating rooms, and ambulatory care settings.

\section{Acknowledgement}

Acknowledgement to the following people for their contribution in making this study a success: Ogwo Jay Umeh, PhD, MBA; Larry Ellis, PhD, and Ernest Black, EdD, faculty at the University of Phoenix, AZ; Suzanne Boyle, DNSc, VP of nursing, NYPH-WCMC, NY; Rey Rivera, DNP, Director of Medicine, NYPH-WCMC, NY and all the critical care nurses who participated in the study.

\section{References}

[1] Press Ganey. About Press Ganey. 2010. http://www.pressganey. com/cs/ about_press_ganey

[2] American Nurses Association Nursing agenda for the future. Washington, DC: American Nurse's Publishing. 2002.

[3] Association of Critical Care Nurses. About critical care nurses. http://classic.aacn.org /AACN/mrkt.nsf /Vwdoc/ About Critical Care Nursing. 2008.

[4] Carr DD. Building collaborative partnerships in critical care. Professional Case Management. 2009; 14(3), 121-131. PMid:19474637

[5] Hain A. How expert professional nurses practice and develop nurse presence in a critical care unit: A grounded theory study. University of Ottawa. Ottawa, Canada. 2007.

[6] Mowday RT, Steers RM, \& Porter LM. The measurement or organizational commitment. Journal of Vocational Behavior. 1979; 14: 224-247. http://dx.doi.org/10.1016/0001-8791(79)90072-1

[7] Williams LL. The fair factor in matters of trust. Nursing Administration Quarterly. 2006: 30(1): 30-37. PMid:16449882 http://dx.doi.org/10.1097/00006216-200601000-00006

[8] Al-Aameri AS. Job satisfaction and organizational commitment for nurses. Saudi Medical journal. 2000; 21(6): 531-535. PMid:11500699

[9] Atkins, P. Mardeen, Marshall, Brenda Stevenson, and Javalgi, Rajshekhar G. Happy employees lead to loyal patients, Journal of Health Care Marketing.1996; 16(4): 14-23. PMid:10169075

[10] Fahad Al-Mailam, Faten. The effect of nursing care on overall patient satisfaction and its predictive value on return-to-provider behavior: A survey study, Quality Management in Health Care. 2005: 14(2): 116-120. PMid:15907021 
[11] O’Brien-Pallas L, Griffin P, Shamian J, Buchan J, Duffield C, Hughes F, Laschinger H. North, N., Stone, P, \& Hayes L. The impact of nurse turnover on patient, nurse and system outcomes: A pilot study and focus for a multi-center international study. Policy, Politics \& Nursing Practice. 2006; 7(3): 169-179. PMid:17071704 http://dx.doi.org/10.1177/1527154406291936

[12] Nogueras DJ. Occupational commitment, education, and experience as a predictor of intent to leave the nursing profession. Nursing Economics. 2006: 24(2): 86-93. PMid:16676751

[13] Krichbaum K, Diemert C, Jacox L., Jones A, Koenig P, Mueller C,\& Disch J.Complexity compression: Nurses under fire. Nursing Forum. 2007: 42(2): 86-95. PMid:17474942 http://dx.doi.org/10.1111/j.1744-6198.2007.00071.x

[14] Loi R, Hang-Yue N, \& Foley S. Linking employees’ justice perceptions to organizational commitment and intention to leave: The mediating role of perceived organizational support. Journal of Occupational and Organizational Psychology. 2006; 7: 101-120. http://dx.doi.org/10.1348/096317905X39657

[15] Wu L \& Norman I. An investigation of job satisfaction, organizational commitment and role conflict and ambiguity in a sample of Chinese undergraduate nursing students. Nurse Education Today. 2005: Article in Press.

[16] Murrells T, Robinson S, \& Griffiths P. Job satisfaction trends during nurses’ early career. BMC Nursing. 2008; http://www.biomedcentral. com/1472-6955/7/7 http://dx.doi.org/10.1186/1472-6955-7-7

[17] Pillay R. Work satisfaction of professional nurses in South Africa: a comparative analysis of the public and private sectors. Human Resources for Health. 2009: 7(15): doi: 10:11 86 /1478-4491-7-15

[18] Al-Hussami M. A study of nurses' job satisfaction: The relationship to organizational commitment, perceived organizational support, transactional leadership, transformational leadership and level of education. European Journal of Scientific Research. 2008; 22: 286-295.

[19] Altuntas and Baykal. Relationship between nurses’ organizational trust levels and their organizational citizenship behaviours. Journal of Nursing Scholarship. 2010 Jun; 42(2): 186-94.

[20] Spector PE. Job satisfaction: Application, assessment, cause, and consequences.Thousand Oaks, CA: Sage.1997.

[21] Health care source. Healthcare talent management: Employee satisfaction is more than just a” feel good” initiative. 2010, June: http// www.healthcaretalentmanagement. Com /../employee-satisfaction-is-more-than-just.html

[22] Ketter P. What's the big deal about employee engagement? Training and Development. 2008: 62(1): 44-49. http://www.f indarticles.com/p/ articles /mi_m 4467/is_200801/ai_n21302720/

[23] HoW H, Chang CS, Shih YL.,\& Liang RD. Effects of job rotation and role among nurses on job satisfaction and organizational commitment. BMC Health Research. 2009: 9: 8 http://dx.doi.org/10.1186/1472-6963-9-8

[24] Lockwood N R. Leveraging employee engagement for competitive advantage: HR's strategic role, HR Magazine. 2007; 52(3): 1-11.

[25] Wagner SE. Staff retention: From “satisfied” to “engaged,” Nursing Management. 2006: 37(3): 24-29. PMid:16518181 http://dx.doi.org/10.1097/00006247-200603000-00007

[26] Upeniek VV, Akhavan J, \& Kotlerman J. Value-Added care: a paradigm shift in patient care delivery. Nursing Economics, 2008: 26(5): 294-300.

[27] Hirschkorn CA, West TB, Hill KS, Cleary BL, \& Hewlett PO. Experienced Nurse Retention Strategies. What Can Be Learned From Top-Performing Organizations. Journal of Nursing Administration 2010: 40: 463-467.

[28] Buerhaus P. The recent surge in nurse employment: causes and implication. Health Affairs. 2009: 28(4): 657-668. PMid:19525286 http://dx.doi.org/10.1377/hlthaff.28.4.w657

[29] Gilmore J. Healthy work environments. Nephrol Nurs J. 2007 Jan-Feb; 34(1): 11. PMid:17345688

[30] Braithwaite M. Nurse burn out and stress in the NICU. Advance in Neonatal Care. 2008; 8: 343-347. PMid:19060580 http://dx.doi.org/10.1097/01.ANC.0000342767.17606.d1

[31] Sabharwal M, \& Corley E A. Faculty job satisfaction across gender and discipline, The Social Science Journal. 2009; 46: 539-556. http://dx.doi.org/10.1016/j.soscij.2009.04.015

[32] Watson L M. Leadership’s influence on job satisfaction. Radiology Technology. 2009; 80: 297-308. PMid:19293118

[33] Davies WR. Mindful meditation: Healing burnout in critical care nursing. Holistic Nursing Practice. 2008; 22(1): 32-36. PMid:18172406

[34] Hamric A, \& Blackhall L. Nurse-physician perspectives on the care of dying patients in intensive care units: Collaboration, moral distress, and ethical climate. Critical Care Medicine. 2007; 35(2): 422-429. PMid:17205001

http://dx.doi.org/10.1097/01.CCM.0000254722.50608.2D 
[35] Coffey C, Tombari N. The bottom-line for work/life leadership: Linking diversity and organizational culture. Ivey Business Journal, 2005.

[36] Maslow A. Motivation and personality. (2nd ed.). New York, NY: Harper \& Row.1970. PMid:5459825

[37] Herzberg F. One more time: how do you motivate employee? In S.J. OTT (Eds), classical readings in organizational behaviour (pp.76-85). Orlando, Fl. 1996: Harcourt Bruce \& Company (original work published 1968).

[38] Mowday RT, Steers RM, \& Porter LM. The measurement or organizational commitment. Journal of Vocational Behavior. 1979; 14: 224-247. http://dx.doi.org/10.1016/0001-8791(79)90072-1

[39] Fiorita K. Bozeman M, Young R, \& Meurs J. Organizational commitment, human resource practices and organizational characteristics. Journal of Managerial Issues. 2007; 11(2): 186-207.

[40] Smith P, Ironson, G, Brannick M, GibsonM, PaulK. Construction of a job in General Scale: A comparison of global, composite and specific measures. Journal of Applied Psychology.1998; 74: 193-200.

[41] CookJ, Hepworth S, Wall T, \& Warr P. The experience of work: Acompendium and review of 249 measures and their use. New York, NY: Academic Press. 1989.

[42] Covey SR. The 8th habit: From effectiveness to greatness. New York, NY: Simon \& Schuster.2006.

[43] KnoopR. Relationships among job involvement, job satisfaction, and organizational commitment for nurses. The Journal of psychology. 1995; 129(6): 643-649. PMid:7500298 http://dx.doi.org/10.1080/00223980.1995.9914935

[44] BozionelosN. “Intra-organizational network resources: How they relate to career success and organizational commitment”, Personnel Review. 2008; (37): 249-263. http://dx.doi.org/10.1108/00483480810862251

[45] GambleJ,HuangQ.“Organizational commitment of Chinese employees in foreign-invested firms”, International Journal of Human Resource Management. 2008:(19): 896-915. http://dx.doi.org/10.1080/09585190801993893

[46] Mathieu JE, Zajac DM. A review and meta-analysis of the antecedents, correlates and consequences of organisational commitment. Psychological Bulletin. 1990; 108(2): 171-194. http://dx.doi.org/10.1037/0033-2909.108.2.171

[47] Lee CH. A study of underemployment among self-initiated expatriates. Journal of World Business. 2005; $40(2): 172-187$. http://dx.doi.org/10.1016/j.jwb.2005.02.005

[48] Sikorska-Simmons E. Predictors of organisational commitment among staff in assisted living. The Gerontologist. 2005; 45(2): 196-206. PMid:15799984 http://dx.doi.org/10.1093/geront/45.2.196

[49] Paige, M. The relationship between job satisfaction and intention to leave of hospice nurses in a for-profit corporation. Journal of Hospice \& Palliative Nursing. 2008; 10(1): 56-64. http://dx.doi.org/10.1097/01.NJH.0000306711.65786.75

[50] Kessuwan K, Muenjohn N. Employee satisfaction: work-related and personal factors. International Review of Business Research Papers. 2010 August; 6(3): 168-177.

[51] Freund A. Commitment and job satisfaction as predictors of turnover intentions among welfare workers. Administration in Social Work. 2005; 29(2): 5-21. http://dx.doi.org/10.1300/J147v29n02_02

[52] Niebuhr B, \& BielM. The value of specialty nursing certification. Nursing Outlook. 2007; 55(4): 176-181. PMid:17678682 http://dx.doi.org/10.1016/j.outlook.2007.02.002

[53] Piazza IM, Donahue M, Dykes PC, Griffin MT, Fitzpatrick JJ. Differences in perceptions of empowerment among nationally certified and noncertified nurses. Journal of Nursing Administration. 2006; 36(5): 277-283. PMid:16705309 http://dx.doi.org/10.1097/00005110-200605000-00021

[54] Fitzpatrick JJ, Campo TM, Graham G, Lavandero R. Certification, empowerment, and intent to leave current position and the profession among critical care nurses. American Journal of Critical Care. 2010; 19(3): 218-226. http://dx.doi.org/10.1097/00005110-200605000-00021 http://dx.doi.org/10.4037/ajcc2010442

[55] Ulrich BT, Lavandero R, Hart K, Woods D, Leggett, Frideman D, D’Aurizio, P, \& Edwards S J. Critical care nurses’ work environments. 2008: A follow-up report. Critical Care Nurse. 2009; 29(2): 93-102. PMid:19339451

http://dx.doi.org/10.4037/ccn2009619

[56] American Association of Critical Care Nures. Nurse Certification Benefits Patients, Employers and Nurses.2010: http://www.aacn.org /wd/certifications /content/benefitstoptempnrs.pcms?menu=certification

[57] Anderson BJ, Manno M, O’Connor P, \& Gallagher E. Listening to nursing leaders: Using national database of nursing quality indicators data to study excellence in nursing leadership. Journal of Nursing Administration. 2010; 40(4): $182-187$. PMid:20305464 http://dx.doi.org/10.1097/NNA.0b013e3181d40f65

[58] Ma C , Samuels M E, Alexander J W. Factors That Influence Nurses’ Job Satisfaction .Journal of Nursing Administration 2003; 33(5): 293-299. PMid:12792284 http://dx.doi.org/10.1097/00005110-200305000-00005 
[59] Ruggiero JS. Health, work variables, and job satisfaction among nurses. Journal of Nursing Administration. 2005; 35(5): 254-263. PMid:15891489 http://dx.doi.org/10.1097/00005110-200505000-00009

[60] McGuire E., \& Kennerly, S. Nurse managers as transformational and transactional leaders. Nursing Economics. 2006: 24(4): 179-185. PMid:16967888

[61] Lewis WF. Critical-care nurses' job satisfaction and its effect on retention. D.H.A. dissertation, University of Phoenix, Phoenix. AZ. 2007. 